YALE

LAW JOURNAL

\begin{tabular}{lll}
\hline \hline Vol. XV. & MAY, I906 & No. 7 \\
\hline \hline
\end{tabular}

\title{
A RECENT CHAPTER OF THE ENGLISH CONSTITUTION.
}

[The following article was prepared, as therein appears, in August of last year. The ill-health of the writer prevented its final cast and revision till very recently. But after all the remarkable recent changes in party and political affairs in Great Britain, it is believed that the essential interest of the topic has not grown less, if indeed it has not grown greater.-EDs.]

It is not the purpose of this article to re-examine the origins of the English Constitution, or to restate at length its peculiar features, or the contrasts it presents to our own. Only enough must be said on these points to make clear the significance of the particular incident which suggests the title of the article.

No one dealing with almost any feature of the English Constitution car afford to overlook or neglect Bagehot's brief book bearing that title,-a work not of professed or formal erudition; but one of profound insight, written in the best style of a great literary master, penetrating to the core of his subject and presenting his ideas with almost unrivalled clearness, simplicity, terseness, and force. Through his few pages we are let into secrets which neither Hallam nor Stubbs nor Freeman have made so clear, even if those great historians themselves perceived them. One of Dr. Johnson's prescriptions for the best writing is-"apt, significant, and sounding words." Bagehot rarely, if ever, indulges in sounding words; as rarely does he fail to use apt and significant ones. In my judgment no writer since Burke, certainly no writer on English or general politics, has had more of the great art-greatest, in many ways, of all literary arts-of gliding easily and naturally into the centre and heart of his theme. Under his hand the English Constitution grows not less, but more, wonderful in its 
surviving quaintness, its complexity, its anomalies and antinomies and over all and in spite of all, its grand adaptation to its great end. With his eyes we see clearly that the English Constitution is not only unwritten, but cannot be finally written, for it is in perpetual flux. Bagehot described it as it was near the middle of what he calls the Palmerston period, the years 1865 and 1866 ; but as he remarks in his introduction to the second edition written in 1872 , "since that time there have been many changes, some of spirit and some of detail." Again he writes: "It is commonly said that "there is not a brick of the Palmerston House standing.' The change since 1865 is a change not of particular details but of pervading spirit." This thesis he amply substantiates, and illustrates by concrete examples.

Bagehot's happiest stroke is the division of the English Constitution into two parts, the dignified parts and the efficient parts. By this one generalization-a generalization not strictly original with this author except in its apt and vivid expression and illustrations at his hands-he at once relieves his subject of the weight and mass of antiquated or obsolete features, and leaves us free to attend to what is of present vital, living force and effect. Antiquity is never to be despised as a present influence, but is often allowed to overburden and obscure what is of more essential interest and importance. Let antiquity play what part it may in theology and ecclesiastical formularies and rubrics; but in secular, especially political, matters let it be relegated for the most part to the background, to the fond care of historians and antiquaries. Such is the precise effect of Bagehot's analysis and synthesis.

The present working parts of the English Constitution-what Bagehot calls its "efficient" parts-as everybody knows or should know-have been largely stumbled upon, hit upon in exigent moments, hammered out in crises to meet present needs, with little thought for distant effects. By inevitable consequence, this Constitution is not a document filled with prescriptions, things allowed and things forbidden; it is a loose, for the most part unwritten, and unsystematic guide or chart for the conduct of affairs, in which precedents hold rather a tyrannical sway, but being only precedents -things done and ended,-may be, as they are, partially or wholly disregarded.

Bagehot and Dicey, the latter writer hardly second to Bagehot in penetrative analysis, and greatly his superior in legal learning and strictly logical acumen, both regard the close union and interfusion of the executive and legislative powers of the English government as the most distinguishing, I might say the most distinguished, 
feature of the English Constitution. The bond and instrument of this union is the Cabinet. The English Cabinet, its function and its method of working, is a specimen of pure evolution, as pure, not as an evolution in physical nature, but as pure as any work made and marred by man's hand, can ever be. It is clear that no man thought out or forecast, even in secret, or in the rapture of prophetic sight, the present development of the English Cabinet. So far as its origin and original design can be discovered or formulated; the Cabinet was merely the monarch's council, intended to be, as for long it was, a body of ministers chosen directly by the monarch and holding at his pleasure. It is but little more than a century and a half-in the reign of George the Second-since the Cabinet ceased to be, in strictness of speech, the monarch's servants. Sir Robert Walpole, so late as 1725 , declared that he had "to manage Parliament, and the palace."

The change from this to the Cabinet of to-day is as far-reaching and furidamental' as can be conceived of in political matters. It is, in fact, an entire reversal, in this time, of the Constitution as it stood so lately as 1725 , if not later. It was a silent change. Not a line of legal enactment proclaimed or recorded or defined it. To apply words first written of quite other things:

"Silently as the daylight Comes when the night is done,

And the crimson streak on Ocean's cheel Grows into the great sun;"

"Silently as the springtime, Her garland of verdure weaves; And all the trees on all the hills Open their thousand leaves:" .

the great entity, called the English Constiution, with its most eminent working instrument, the English Cabinet, began, grew and took shape.

In direct contrast to the practice, the Constitution, of former but not distant days, the head of the Cabinet is now fixed, not by the monarch, not even by Parliamen't, but by the House of Commons alone. He must be, whether a member of the House of Commons or of the Lords, the leader, not of Parliament as a whole, or of either House as a whole, but of the dominant, prevailing party in the House in which he sits, and by proxy, of that party in the other House. His colleagues, selected by him, are, not necessarily, though in practice chiefly, members of the House of Commons who alone represent the people of the realm and are presumed to reflect 
their sentiments. They must all be members of the prevailing partyprevailing, that is, either in a general election, or in votes in the House of Commons.

Into further details of the working of the Cabinet idea as now developed in practice in England, this is not the time to go; but one or two contrasts with the working of our system ought to be pointed out before we turn to the incident by which we purpose to illustrate the indeterminate, or rather the undetermined, character, what we may well enough and more graphically call the fluidity, of the English Constitution.

The fundamental theory in the United States, the theory of our system, is the separation of three chief departments of government, -the independence of each with respect to both the others. I think this theory is carried in our system practically about as far as is possible. The three departments cannot be absolutely separated in the nature of things. Our legislative power is not wholly dissevered, even directly, from the Executive. Every law of the land requires the action and assent of the Executive, or passage over his objections, or lapse of time for stating the executive refusal or objections.

The power of appointment to most of our principal offices is a joint function of our Executive and our Senate. The judiciary, too, is appointed by the Executive; but his action is only initiative. It must be confirmed by the Senate. Independence, therefore, between these departments is only relative and sub modo.

But in England there is nothing that answers to the idea of independence between the monarch and Parliament; nor is even the judiciary kept out of politics. The highest judicial officer of England, the Lord Chancellor, goes in and goes out with the ascendant political party; he acts as a strict partisan as a legislator; he goes upon the hustings like any other political partisan. It must be said, however, that in all judicial duties and functions the English Lord Chancellor's standing does not seem to be lowered or the confidence in his judicial acts impaired, by his political partisanship; so strong is custom and the English sense of the sacredness of the judicial function.

Quoting once more from Bagehot a striking and most illuminating summary of the position of the Cabinet: "The Cabinet is a combining committee-a hyphen which joins, a buckle which fastens the legislative part of the State to the executive part of the State. In its origin it belongs to the one; in its functions it belongs to the other." It need not be remarked how utterly diverse and contradictory to all this is the Cabinet in the United States, where it is 
only the personal choice, in the first instance, of the Executive, the power of confirmation by the Senate being by custom merely nominal. I do not know that a nomination of a member of the Cabinet has ever been disallowed by the Senate except where the nominee was barred by some positive law.

Interesting as it might be to continue these reflections, I must not longer dwell on them, but come to my subject proper, enough having been said to put us fairly en rapport with my special topic.

The incident which I have ventured to call a chapter of the English Constitution, concerns primarily and most directly the Cabinet, the unique and most efficient part of the Constitution; and in the second place, it vitally concerns the position and power of the House of Commons.

It is a prime, essential requisite of the Cabinet, as matter of theory and equally of practice, that it should always represent the preponderant political party in the House of Commons. It is an almost necessary consequence of this requirement, that whenever the Cabinet of government, as it is called, ceases to be so representative, it must retire. Two courses, according to all precedents and practice, and only two, are open to it in such case: first, it may resign and thus allow the Opposition, so-called, to form a Cabinet or government; or secondly, it may appeal to the country by dissolving Parliament, that is, putting an end to the life of the existing House of Commons and ordering a new election. Pending such election the existing Cabinet remains in office. If the election results in the choice of a majority favorable to the existing government, it remains in office; if a majority of the members elected are opposed to the existing government, the Cabinet retires and their opponents, called the Opposition, take their places. All this is intelligible and easily practicable except in one respect; and this is the point and theme of the present paper, namely: When, under what circumstances, can a given Cabinet or government be said to cease to be representative of the House of Commons or to lose the confidence of the country? This is a query more easily put than answered. If the test were alone-In a given House of Commons, does the Cabinet represent the House?-the query might be readily and mathematically answered by a test vote in some issue of importance in the House.

But, confessedly, such a show of hands is not alone sufficient. It is quite possible, and is often the fact, that the House may support a government after an adverse vote, the vote being the result of absence of members, or other circumstances not going to the merits of the subject voted on. If no other consideration is involved 
the Cabinet may constitutionally, that is, let me repeat, may according to recognized and established custom, for there is no other guide or compulsion, continue in office. To substantiate the latter remark, let me here quote the terse, epigrammatic dictum or doctrine laid down, on an important occasion, by the late Lord Salisbury: "Your Parliamentary Constitution," said he, "of which you are so proud, is written in no statute; it rests on long traditions, and understandings honorably observed."

But if it further appears, by whatever evidence, that the House no longer represents the true political sentiment of the country as a whole, though still holding a majority in the present House, what then is the constitutional duty of the existing government? Plainly this is not a question easy of answer. Here it should be remarked and borne in mind that it is a fundamental English idea or notion that the government should always be truly reppresentative of and responsive to the general dominant political sentiment of the country as a whole, as well as of the House of Commons. I do not think this statement can be successfully controverted, or that it is anywhere denied. But the difficulty lies in the application of the principle. A vote in the House is an easy test to make; but the state of opinion in the country is difficult of ascertainment, except through an election at large.

If then, a Cabinet or government still commands a majority of the House of Commons, and declines to go to the country by ordering an election, what is the situation and what its solution? I think a satisfactory answer is rather difficult. Several queries, one crucial, here arise. Thus, how shall it be determined whether the country supports the existing Cabinet or not, in default of a general election? This seems to be the exact question presented by recent proceedings in the present House of Commons and by the circumstances in which the Balfour government was then placed. It is, therefore, necessary to state, in due order and detail, the facts which made up the situation. Let us, therefore, first try to get the exact facts, regardless of any preconceived or desired conclusion, and with a single eye to accuracy of statement. It cannot be necessary for me to say that the fate of an English ministry of whatever party, or the success or defeat of either of the two great historical parties of England, has no personal concern or interest for me, except as any important event may be said to concern all the world.

In all references to the debates or proceedings on July 2oth and 24th, I shall rely entirely on The London Times' reports in its issues of July 21 and 25, I905. 
In the session of the House of Commons on Thursday, July 20, I905, the House being in what is called, in parliamentary parlance, "Committee of the Whole," was engaged in the consideration and discussion of what is called "Supply" on the Irish Estimates, that is, allowances or appropriations for the expenses of the Irish Land Commission; whereupon Mr. John Redmond, leader of the Irish Nationalist party in the House, moved to reduce the amount proposed by the government by the sum of 100 pounds, a well-recognized form of motion, designed of course to raise and allow discussion of the whole subject of Irish administration. The debate accordingly went on from three o'clock, afternoon, to twelve, midnight, when the debate was automatically, as it is termed, that is, by permanent rule of order of the House, closed and a vote or division was taken on Mr. Redmond's motion or amendment. The division resulted in 199 votes for the amendment and 196 against the amendment, the government being thus defeated by a majority of three, afterwards corrected to four. The Prime Minister, Mr. Balfour, thereupon declining to announce at once the course he would pursue in view of this defeat, the House adjourned, the Prime Minister promising to state his decision on the following Monday, July 24, I905; and on that day he informed the House that for reasons stated at length, and upon precedents recited by him, the Cabinet would not resign. He gave no indication regarding a dissolution of the House and a general election.

This statement is believed to cover all the essential facts of the case. Let us scan their significance.

It will be seen, first, that the vote occurred in what was a full, an unusually full, House, wanting but four of 400 members present and voting, the total number of members of the House being 670 .

Next, the division was taken at the close of a long debate.

Third, not only was it done in an actually full House, but only two days previousy the Prime Minister had met his party in what in the United States would be called a caucus, and had specially warned them of the dangers of defeat, and adjured them to be at their posts on all occasions when a serious division could occur.

In addition to this, what are called "whips" had been issued by both parties, that is, written calls upon members to be present in view of exigent contingencies, the "whip" or call being framed and sent out by regularly appointed representatives of the two parties, themselves called "whips," to every member of the respective parties. These whips were what is called "three line" whips, that is, whips of the highest urgency.

Fourth, the debate and division followed upon an elaborate 
statement of the Chief Secretary for Ireland of a government scheme for the amendment of the Irish Land Act of 1903, known as the Wyndham Act, which would have required a bill for its carrying out. It was, therefore, as the London Times, a strong supporter of the Balfour government, pointed out editorially the next morning, tantamout to, or in the nature of, a defeat of the government on the second reading of a bill, a result always heretofore regarded, it is believed, as of prime gravity in determining the fate of governments in the House of Commons; though The Times later said it was "an entirely novel theory that a government must resign upon a defeat in supply." Times, July 21 and August I, I905.

All these elements were present in this division and, taken alone, they may be said at once to point to and prescribe the choice by the government of the alternative of resignation or dissolution.

On the other hand, the majority against the government was very small. How far this is a fair consideration, by itself, is a question. Certainly, it cannot be said that it concludes the question or resolves all doubts.

Again, it is a clear fact that the result was due to the absence of members who, if present, would have voted with the government. How far, if at all, this fact, which cannot be disputed, affects the force and validity and proper or usual consequences of a clear numerical defeat, is likewise a question to be considered.

Taking it, then, as certain that the defeat was a fair one, given under circumstances which do not permit any candid mind to regard it is a "snap" judgment or, on its face, open to any serious discount; taking it, on the other hand, as certain that a majority of the present House of Commons are supporters of the present Cabinet or government; that such has been, was at the time of this division, and is now, the indubitable fact; * how stands the case?

If this were the whole case, we might now render an answer to our questions; but it is by no means the whole, perhaps not nearly the whole, of the case. This point we must elucidate clearly, if possible. The life of a given House of Commons is seven years only. At the end of that period there must be a new election. The last general election prior to July I905, took place in September and October, I900. This was in the middle, or nearly so, of the Boer War. That war, as all will remember and agree,-its continuance to a finish,-was almost the sole issue of the election of Ig00. It may be said, with perfect certainty, that that issue controlled

*See the editorial note prefixed to this article. 
and determined the election. Five years have passed since that election and with those years has passed the issue of the Boer War, the issue which determined the political complexion of the present House of Commons.

The extreme partisan claim is sometimes made, by the present opposition, or some of them, that these facts take away all moral authority from the present House to deal with other great issues. The force of the claim may be considerable, but it can hardly bear being stretched to such an extent. I do not doubt, however, that if no partisan interests were at stake the consensus of English opinion would be to the effect that the most patriotic and becoming course would be for the present government to dissolve Parliament,the House of Commons, - and go to the country on present issues; but I cannot see that the fact alone that the election of I900 turned on a single issue now closed, makes it unconstitutional or strictly improper, in any sense, for the present government or House of Commons to continue to carry on the business of the country.

But there is another fact, a very great fact, to be reckoned with; namely, the fact of the by-elections of the last two years, that is, elections of members of the House to fill vacancies arising from death, resignations, or other causes. From the close of the Boer War till this date, August, 1905, fifty by-elections have taken place in all parts of the Kingdom. These contests-all the elections were contested-have resulted in the loss to the Conservative or Balfour party of twenty seats, or fifteen per cent of the Conservative majority at the last general election. The results in some of these contests were specially remarkable and significant of the trend and condition of political sentiment in the country at large, notably the Brighton election in the spring of 1905, where a revolution occurred in a conservative district and under a leader and candidate on the conservative side of great prominence and ability.

$\mathrm{Mr}$. Gladstone in 1874 , writing to his colleague, Earl Granville, said in substance that no number of adverse by-elections could, by themselves, afford a constitutional cause for resignation or dissolution. ${ }^{1}$ Probably Mr. Gladstone was right in this; and though Mr. Balfour attached much value to the opinion, it does not apply to the present case. Here by-elections did not stand alone or by themseives; beside them stood, as has been said, a defeat of the government, on a vital question touching the whole Irish policy of the government, in a full House, after a protracted debate, and under the spur of urgent "whips."

r. Morley's Life of Gladstone, II, 480. 
As bearing on the question of the sentiment of the country byelections are always regarded as important, as they certainly are in the nature of the case. It is claimed by many that the result, as stated, of the by-elections since 1903, or during the last two years, is conclusive of the sentiment of the country; and the further claim is made that as the House ought always to be the mirror of the country, and that such a conception is virtually a part of the English political system, a Cabinet or government finding the byelections going strongly or preponderatingly against it for a considerable time ought, under its constitutional obligation, to resign or dissolve.

There is certainly force in this general dogma. If the House ought constitutionally to refiect the country, it should seem that when it ceases to do so, it ought constitutionally to give away. We think such would be the judgment of all, or nearly all, informed minds, if party interests were laid aside.

But here comes in the patent difficulty: Who shall decide, and how shall it be decided, whether and when the course and adverse result of by-elections is so clear, so clearly significant of but one condition of opinion of the country, as to make it constitutionally obligatory on an existing government to retire?

Plainly no answer but a most general one, can be given to this question. An existing government must act at its risk and on its responsibility. There is no absolute compulsion anywhere, no strict line to which it may go and beyond which it may not go. If its choice puts it in an unconstitutional attitude, it cannot be said to be illegal.

It is worth noting at this point that while in the United States, the words illegal and unconstitutional are not strictly synonymous, yet nothing in the United States can be unconstitutional which is not illegal. Unconstitutionality there connotes not only illegality but the highest form of illegality. In England it is quite otherwise, a result and contrast due apparently to the fact that the Constitution of the United States is a written constitution which overrides all other law or legal obligations, and furnishes a touchstone for every occasion of the exercise of public powers.

To gather up into one expression the results of the study of the incident of July 20, I905, and its immediate sequel, it seems just and accurate to say that where an existing government is beaten in the House of Commons ( $I$ ) on a fair and notified occasion, (2) in a full House (3) on a serious and vital question of administration or of policy, and (4) when in addition it appears that the by-elections are, and have been, for a considerable period, running 
heavily and steadily against it, the only constitutional course of the government is resignation or dissolution.

From all that has now been said it would seem to follow that Mr. Balfour wrote a new chapter of the Constitution, so far as in him lay, when, under the circumstances now set forth, he chose to retain office and refused to dissolve Parliament. The fault or fallacy of Mr. Balfour's statement and argument is that he persists in ignoring a part, a large part, an essential part, of the case. Reasonable men, men not too much swayed by apparent immediate party interests, do not hold that a defeat by four, even in a full and notified House, on supply or on any motion, by itself alone, compels resignation or dissolution, especially when the government still has a clear majority of supporters in the House. Such is not this case. The case is that not only has the government been fairly, quite fairly, beaten on the Redmond motion, but it has been steadily beaten, beaten to the extent of over thirty times, in by-elections in the last three years. This latter fact cannot, taken alone, compel retirement or an appeal to the country. The true claim is that the defeat in the House and the by-elections, taken together, constitute a situation in which the Constitution, that is, constitutional custom of the most rigid sort, drives, or should drive, the government to resignation or dissolution.

It was easy for Mr. Balfour, it would be easy for anyone, to find precedents which did not expressly forbid the course he wished and elected to take. It did not require a dialectician: of his high acknowledged astuteness and ability to do that. Precedents, socalled, are, as Judge Story once remarked, "knavish things, for they will serve any side or all sides of a case." Precedents grow out of sets of circumstances; circumstances make precedents. The facts, the circumstances, must therefore rightly have the first consideration in examining precedents. No two sets of circumstances are ever quite alike. It was found, after death, that the Siamese twins, Chang and Eng, differed by about the one thousandth of an inch in the length of their ears. What competent lawyer, or intelligent layman, cannot discriminate and distinguish, often satisfactorily, between what are at superficial view the very closest precedents? Not one of the array of precedents put forward by Mr. Balfour was really closely parallel with the case before him or formed a just precedent for his course.

I am aware that this is a very broad and quite sweeping statement which ought not to be made except upon sufficient evidence. Before making it, I have, therefore, looked up and examined all the precedents made use of by Mr. Balfour in stating his case for 
retaining office on July 24, I905,-a thing which I have not observed to have been done by others.

In his statement of July 24th, Mr. Balfour used many loose general expressions in referring to the history of former administrations. He speaks of their suffering "many defeats," "series of defeats," "successive defeats," and as "often defeated." It is impossible to deal with such statements or to trace out their origin. I shall be obliged of course to confine myself to such historical examples, or precedents, as are by him singled out and named.

The statement of $\mathrm{Mr}$. Balfour traverses a period of sixty-six years, I839-1905. Beginning with the Melbourne administration in 1839 and citing ( $I$ ) the action of that administration under defeat, he passes rapidly over all intervening administrations down to the Gladstone administration in 1872 which he cites (2) as his second precedent, and (3) the action of the same administration in 1873 , and (4) again in 1893 , and closes with a reference to (5) what he calls Lord Rosebery's defeat on Address in I894.

Five specific cases are thus presented as the historical and constitutional defense of the refusal to resign or dissolve in July, I905.

The first precedent (Melbourne, I839). The government of the day had brought in a bill known as the Jamaica Government Bill. Lord John Russell, the government leader in the Commons, was in charge of the bill. The bill was debated from the date of introduction, April 9, 1839, with intervals, till May 6, 1839, when the House divided with the result of 289 for, and 294 against, the bill, a defeat of the government by five votes. The next day, May 7th, Lord Melbourne in the Lords and Lord John Russell in the Commons, announced the resignation of the Cabinet. Sir Robert Peel was then asked to form a government, whereupon the difficulty of the Ladies of the Bedchamber arose and Peel, in consequence, declining to accept office, Melbourne and his Cabinet resumed duty as before defeat. ${ }^{2}$

This precedent, so far as it bears, seems to condemn the refusal of the Balfour administration to resign. The majority against the government was, as in the present case, very small. There is no evidence that the government feared defeat or made any special effort to prevent it; the fact that Melbourne was able to resume and carry on business seems to show that he still had the confidence of the House; and by-elections cut no figure whatever in the situation. Still Lord Melbourne promptly resigned under these circumstances.

2. Hansard, Vols. 46, 47, (1839) pp. 209, 210, et passim. 
The second precedent (Gladstone, I872). The government of the day had introduced a bill entitled "A bill to amend the Law relating to Procedure at Parliament and Municipal Elections," February 8, I872, a bill which Mr. Balfour calls the Ballot bill. The bill was under debate from the above date to April 18, I872, when upon an Opposition amendment, opposed by the government, the government was defeated, on division, by twenty-eight majority. Mr. Gladstone expressly stating in the Commons that he did not consider the amendment fatal or greatly injurious to the bill, remained in office and the bill was passed in the Commons April 29, I872. ${ }^{3}$ The House of Lords amended the bill in points regarded essential by the Commons who refused concurrence; the Lords did not insist on their amendments; and the bill received the royal assent, July 18 , 1872.4

This precedent has slight force, if any, in the present case. Mr. Gladstone declined to resign on the express ground that the bill was not essentially damaged by the adverse amendment. No evidence appears that the division on which the government defeat took place was prepared for by either party, nor did byelections figure in the case

The third precedent (Gladstone, I873). In this case the government was defeated on its University Education (Irish) bill by a majority of three. Mr. Gladstone resigned, and Mr. Disraeli was invited to form a government. This, after some effort, he declined to do on the ground (I) that a majority of the House of Commons were opposed to his party, which would make it impossible for him to carry on the business of the country; and (2) that he could not, in the then state of the country politically, advise a dissolution. Thereupon Mr. Gladstone resumed office. ${ }^{5}$

This precedent seems in its essential facts to go against $\mathrm{Mr}$. Balfour's course on the present occasion. Mr. Gladstone promptly resigned on a defeat by. three, one less than on Mr. Balfour's present defeat. No evidence appears to show that the defeat in I873 was prepared for by either party; and Mr. Disraeli's reasons plainly show that both the House of Commons and the country were still with Mr. Gladstone, as the sequel also plainly showed.

The fourth precedent (Gladstone, I893). Of Mr. Balfour's fourth alleged precedent, it is to be said shortly that there is no such precedent. Mr. Gladstone was not "beaten," as Mr. Balfour stated, "in

\footnotetext{
3. Hansard, Vols. 207, 210, (1872) passim.

4. Idem, Vols. 207, pp. 520, 665, 68I, 885. (1873).

5. Hansard, (I873) Vol. 2I4, pp. I863, Ig09, I924.
} 
I893 on a vote as to the House of Lords." No such vote even took place under Mr. Gladstone's administration. Mr. Balfour has apparently confused the vote on the address under Lord Rosebery in I894 with Mr. Gladstone's administration. No further attention need be given to what on its face is Mr. Balfour's fourth precedent.

The fifth and last precedent (Rosebery, 1894). A general election for members of the House of Commons took place in I894, the result giving the so-called Liberal party a substantial majority. Lord Rosebery became Prime Minister and on March I2, I894, Parliament was opened by the Queen's speech and the usual address in reply was moved by the government. Mr. Labouchere moved an amendment calling on the Queen, in effect, to suppress the House of Lords for obstruction of legislation passed by the House of Commons. The division on this amendment resulted March I $3^{\text {th }}$, in 147 ayes, and 145 noes, a majority of two. On the next day Sir William Harcourt announced the position of the government towards this amendment; namely, that the government would not support the address as originally moved with this amendment added; and that hence the government would vote down or negative the address as it thus stood, and would propose another address in the terms substantially of the one first proposed. This was done; and the second or new address was moved and adopted nemine contradicente.

Plainly there is nothing in this precedent which tends in any way to support Mr. Balfour's position on July 24, I905. An adverse vote in address would no doubt, if moved and carried by the Opposition, be cause of retirement; but Mr. Labouchere was a government supporter and the amendment was not moved or passed as an attack on the government. The government, therefore, was not called on to act as if under defeat. It does not appear that any one hinted that the passage of the Labouchere amendment was a government defeat, in any proper or effective sense. ${ }^{B}$

My characterization of Mr. Balfour's precedents and the result of their examination are not to accuse or convict him of conscious unfairness or chicane; it resulted from the nature of his material. I will venture that quite as good a case could have been made out from his precedents, by one of equal ability, for a conclusion diametrically counter to the one he reached.

It certainly will not avail much to attempt to minify or depreciate the force, the proper constitutional effect, of the adverse vote

6. Hansard. (1873) Vol. 22, (1894) pp. 3-293 passim. 
of July 2oth by calling it, as the supporters of the government are now calling it, "a mere vote on Supply." It should seem that any motion, however trivial its subject, if put forward by the opposition, or by any party or member, and accepted by the government as a test of strength or confidence, becomes a valid test and ought to be so regarded and treated. Nor is the suggestion of more value that the motion of July 20 th was not made by the leader or other member of the regular opposition. If, by whomsoever made, the motion in fact becomes a trial of strength, accepted as such by both parties, between the government and its opponents, the consequences of defeat cannot constitutionally be avoided.

I have used the expression that Mr. Balfour "wrote a new chapter." I mean only that he attempted to do so. I do not believe his action will grow into a precedent, or a chapter and part of the English Constitution. It may be a warning precedent, but hard$1 y$ more.

I have omitted till now to state that Mr. Balfour's affirmative claim was virtually that only a direct challenge or attack on the Ministry by the recognized opposition and apparently in the form of an express motion of censure or want of confidence, a "frontal attack directly challenging the whole general policy of the government and made by the opposition eo nomine" going against the government by a decided majority, could compel resignation or dissolution. Certainly not one of the precedents cited by him sustains this position.

Perhaps a word of explanation is needed regarding the last item of this claim. The motion on which the government was defeated July 2oth, was made, as has been said, by Mr. Redmond, leader of the Nationalist (Irish) party or contingent in the House, and not by Sir Henry Campbell-Bannerman, the leader of the Opposition, so-called. The Opposition, however, unanimously supported the Redmond motion. The claim of invalidity of the defeat on the ground last named, seems as a matter of reason, to have no ground or weight, nor has any one cited a precedent to sustain it. The real result of all the precedents, as well as the principles, applicable to this case, seems to me to be that under whatever form or circumstances it appears that the government has lost the confidence of the House and of the country, the government's duty is clear to resign or dissolve. To wait for a formal vote of censure in the House is not the constitutional mode of testing the validity and right of an English Ministry to hold office. Nor do I believe, as I have said, that such a doctrine will be grafted permanently on the English Constitution. 
Whoever would study the political and constitutional principles involved in the crisis of July 20 , I905, ought not to fail to read and ponder Mr. Dicey's Eighth Lecture. ${ }^{7}$

My own impartiality of mind in reaching my conclusion must be judged of, not by my professions, but by the manner in which I have treated the subject-matter of this article.

London, August, I905.

D. H. Chamberlain.

7. A. V. Dicey, Law of the Constitution, especially pp. 33 I-364. 